\section{DYSKUSJA PANELOWA}

\section{Stanisław Zapaśnik}

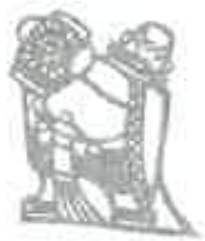

\section{PROBLEM PRAW CZLOWIEKA W CHINACH}

Nie podzielam obaw prof. Stanisławskiego, że dyskusja nad problemem praw człowieka w Chinach, prowadzona z udziałem uczonych specjalizujących się w kulturze chińskiej, bedzie sprzyjała relatywizacji ocen moralnych. Jestem bowiem przekonany, że większość obecnych tu moich kolegów dokonała identycznego jak ja wyboru. Jako badacz kultury stosuję obowiazująca w takich badaniach zasadę relatywizmu metodologicznego. Jako człowiek odrzucam jednak relatywizm kulturowy $\mathrm{i}$ jestem przeciwny interpretowaniu zasady tolerancji jako zgody na występowanie takich praktyk, jak stosowanie kary śmierci nawet w tych krajach, o których wiem, że stosunek do tego rodzaju wyroków jest uwarunkowany przez kulturę i za ich stosowaniem opowiada się ogromna większość społeczeństwa.

To prawda, że kultura chińska jest na tyle różna od zachodniej, że może się wydać nawet całkowitym jej przeciwienstwem. Nie będę jednak mówić o tych różnicach, choć przypuszczalnie temu, że specjalizuję się w badaniach kategorii myślenia, w tym pojęcia jednostki ludzkiej w kulturach azjatyckich, zawdzięczam zaproszenie mnie do udziału w tej dyskusji. Chciałbym zwrócić uwagę na pewne kwestie zwiazzane $\mathrm{z}$ instrumentalizacją problemu praw człowieka w Chinach $w$ polityce międzynarodowej, przede wszystkim zaś w polityce zagranicznej Stanów Zjednoczonych.

W socjologii amerykańskiej dawno już zauważono, iż spadek aktywności wyborców w USA spowodował, że partie polityczne walczą obecnie ze sobą na innych polach niż kampanie wyborcze, bo te straciły poprzednie znaczenie. Jednym z najważniejszych symptomów zaszłych zmian są nowe relacje między Kongresem a prezydentem. Stało się zwyczajem, że w wyborach do Kongresu większość zdobywają przedstawiciele tej partii, której kandydat przegrał rywalizację o uriad prezydenta. W ostatnich kilkunastu latach było więc reguła że jeżeli prezydentem zostawal kandydat demokratów, w wyborach do Kongresu więcej riejsc uzyskiwali republikanie i odwrotnie. Otóż nowym zjawiskiem w polityce amerykańskiej jest, że Kongres nie współpracuje z prezydentem, natomiast każda partii stanowiących w nim większość stara się wykorzystać tę instytucję do da t. paniczenia i osłabienia władzy wykonawczej. W tych wanunkach, zarówno Izba, ogra Senat dąża do rozszerzenia liczby personelu i uprawnień komitetów i podkoinitetów, aby mogły one monitorować i nadzorować działania administracji zadowej. Jedną z płaszczyzn walki Kongresu z prezydentem jest właśnie kwestia praw czlowieka w polityce zagranicznej USA.

Kiedy niedawno poszukiwałem literatury naukowej dotyczącej roli praw człowieka w polityce zagranicznej USA, znalazłem jedna tylko pozycję artykuł Calvima Mackenzie Resolving policy differences: foreign aid and human rights, w pracy zbiorowej poświęconej - co nie jest przypadkiem - walce Kongresu z władzą wykonawcza o kontrolę nad amerykańską polityką zagraniczną. Jest to wprawdzie dość już stare opracowanie, bo wydane zostało w 1994 r. O ile zdołałem stwierdzić sledząc przez parę ostatnich lat sprawozdania z działalności Kongresu publikowane w „Washington Post” i „New York Times” - od 1994 r. nie zaszły zmiany, które by kazały uważać przedstawiony w tym artykule opis komisji Kongresu i metod ich działania za nieaktualny.

Wydawać by się mogło, że sytuacja, kiedy to władza ustawodawcza dominującego mocarstwa stara się uzależnić pomoc zagraniczną rządu dla poszczególnych państw od warunku przestrzegania przez nie praw człowieka jest wręcz idealna dla umocnienia obowiazywania tych praw w świecie. Twierdze jednak, że tak nie jest $\mathrm{i}$ to $\mathrm{z}$ paru powodów. Po pierwsze Kongres nie ma ustawowych środków, które pozwoliłyby mu skutecznie zablokować niepożądaną w opinii jego członków decyzję administracji waszyngtońskiej. Do wyłącznej kompetencji tej ostatniej należy bowiem interpretacja, czy dany przypadek zasługuje na ocenę jako poważne naruszanie praw człowieka.

Dlatego wielokrotnie się już zdarzało, że mimo opozycji Kongresu pomoc USA była jednak udzielana krajom, o których opinia amerykańska była przekonana, iż nie są w nich przestrzegane najbardziej nawet elementarne standardy praw człowieka. W takich bowiem przypadkach władza wykonawcza może na mocy obowiązującego ustawodawstwa uzasadnić swoje działania odwołując się do „wyjątkowych okoliczności”, takich jak „interesy bezpieczeństwa narodowego" "czy wzgląd na to, że pomoc ta "przyniesie bezpośrednią korzyść ludności" kraju, któremu została udzielona. Są to zresztą z reguły takie przypadki, gdy trudno jest uzyskać konsensus również w samym Kongresie, ponieważ wielu jego członków uświadamia sobie, że konsekwencją odmowy przyznania pomocy może być utrata wpływu USA na politykę danego rządu. Inna sprawa, że jak wiadomo, 
niekiedy to Kongres sprzeciwia się wstrzymaniu pomocy wówczas, gdy whiosek taki wychodzi od władzy wykonawczej. Wynika to $z$ samej logiki sytuacji, istot której jest walka tych dwu władz.

Po drugie - $\mathrm{i}$ to być może jest nawet ważniejsze - środki, jakimi dysponuje Kongres w celu monitorowania przestrzegania praw człowieka w świecie są bardzo ograniczone. Jak twierdzi cytowany przeze mnie autor, w 1994 r. brak środków nie pozwalał Kongresowi monitorować sytuacji w dziedzinie praw człowieka aż w 150 krajach. Od tego czasu, o ile wiem, niewiele się zmieniło. Nada źródłem wiedzy Kongresu o stanie respektowania praw człowieka w wielu krajach są ekspertyzy zamawiane przez organizacje pozarządowe i rozmaite grupy interesów. To właśnie stanowi jedną z ważniejszych przyczyn, dla których Stany Zjednoczone tak często występują w sprawie praw człowieka w Chinach. Nie jest dla nikogo tajemnicą istnienie potężnych lobby dążących do ograniczenia importu towarów chińskich na rynek amerykański. Do niedawna były to przede wszystkim lobby przemysłów stalowego, obuwniczego i tekstylnego. Od jakiegoś czasu dołączyły do nich także lobby przemysłu narzędziowego i komputerowego. $Z$ publikacji w prasie amerykańskiej można się dowiedzieć, że kwestia przestrzegania praw człowieka w Chinach jest przez te lobby wykorzystywana w ich celach.

Nie jest to bynajmniej jedyny znany mi przypadek czysto instrumentalnego traktowania tej kwestii w polityce. W 1998 r. "Sydney Morning Herald" opublikował cykl artykułów, które opisywały w jaki sposób rząd australijski przekonał Międzynarodowy Komitet Olimpijski do wyboru Sydney jako miejsca przysziej olimpiady. Rywalem Sydney był Pekin. Zwycięstwo Sydney było możliwe także i dlatego, że rząd Australii przez dwa lata finansowal w świecie kampanię w obronie praw człowieka w Chinach. Innym nasuwającym się w tym kontekście przykładem byłyby działania rządu na Tajwanie. Stałą pozycją w budżecie tego państwa są wydatki na kampanię propaganđowa mająca zjednać poparcie światowej opinii publicznej dla Tajwanu. Tamtejsza propaganda szczególnie koncentruje się na przypadkach naruszeń praw człowieka w ChRL, ponieważ uwiarygodniają one obraz tego państwa jako komunistycznej dyktatury.

Będęjednak mówił o skutkach instrumentalnego traktowanie kwestii praw człowieka w polityce zagranicznej USA. Podróżując jesienią 1999 r. po Azji Centralnej spotkałem tam powszechny antyamerykanizm. Jak mi wyjaśniano, genezą tego zjawiska jest rozczarowanie podejściem rządu Stanów Zjednoczonych do kwestii praw człowieka w świecie. O tym, że Stany Zjednoczone traktują tę kwestię wyłącznie instrumentalnie, słyszałem nie tylko od przedstawicieli rządów, ale także od działaczy organizacji zajmujących się obroną praw człowieka, w tym również takich, które w swojej nazwie podkreślają że jest to organizacja działająca przy współpracy amerykańskiej. Moja podróź zbiegła się $z$ ujawnieniem przez rząd USA decyzji o przyznaniu pomocy wojskowej Uzbekistanowi. Waszyngton krok ten dniał potrzebą wsparcia Uzbekistanu przed zagrożeniem ze strony fundaursis istów islamskich. Jednak moi rozmówcy w Azji Centralnej byli świadomi mentalisto paru już lat Uzbekistan jest krajem szczególnie uprzywilejowanym teggo, że od parú juz Zjednoczonych w tym regionie. Wiedzieli także, na jak szeroką skale reżim A. Karimowa stosuje represje dążąc do zlikwidowania opozycji roką skalę

Zwracam uwagę że o ile wszystkie środki masowego przekazu na Zachodzie formuja stale o prześladowaniach Falung Gong w Chinach, o tyle o prześladoin formują stale o prźs. odmawiających udziału w ściśle kontrolowanym przez pańswo tzw. oficjalnym islamie w Uzbekistanie wiedzą nieliczni tylko eksperci specjalizujący się w problemach Azji Centralnej. Według źródeł opozycyjnych w samym Uzbekistanie w sierpniu $1999 \mathrm{r}$. w więzieniach przetrzymywano - nierzadko bez wyroku sądowego -50 tys. muzułmanów. Wystarczy porównać tę liczbę z liczbą mieszkańców (ok. $25 \mathrm{mln}$ ), by pojąć skalę zjawiska. Na Zachód zaczęły docierać wtedy i docierają nadal niemożliwe do sprawdzenia doniesienia o obozie nad Morzem Aralskim, w którym przetrzymywani są aktywiści islamscy. Można usłyszeć, że obóz zbudowano na miejscu dawnego poligonu, na którym przeprowadzano eksperymenty $\mathrm{z}$ bronią atomowa. Wysoka radioaktywność w tym miejscu miałaby wyjaśniać przyczyny dużej śmiertelności wśród więźniów.

Zdaję sobie sprawę z uwarunkowań polityki USA w Azji Centralnej, które powoduja że aby umocnić swoje wpływy w tym regionie bogatym w złoża surowców energetycznych, przede wszystkim ropy naftowej, wielkie mocarstwo jest skazane na sojusz z państwem takim jak Uzbekistan. Jest jednak inna strona tego problemu. Walka Kongresu z prezydentem spowodowała, że komuś, kto nie orientuje się w mechanizmach polityki amerykańskiej będzie się wydawało, że prawa człowieka są najważniejszym kryterium polityki USA w stosunkach $\mathrm{z}$ innymi państwami. W każdym bądź razie od czasów prezydentury Cartera są to sprawy najczęściej omawiane przy okazji dyskusji w Kongresie nad polityką zagraniczną USA. Niejasności w tym względzie powstają też wskutek niektórych działań dyplomatów amerykańskich. Zdarzają się wypadki, że aby uniknąć kwestionowania przez Kongres amerykańskiej polityki zagranicznej w stosunkach $\mathrm{z}$ danym krajem, dyplomacja USA z pozornie dobrą wiarą przyjmuje zapewnienia rządu, uważanego za autorytarny, że zmienia on swoją politykę wewnętrzną. Niedhugo przed planowaną podróżą prezydenta Karimowa do Waszyngtonu w końcu 1996 r. otwarto w Taszkencie, stolicy Uzbekistanu, z inicjatywy rządu Narodowe Centrum Praw Człowieka. Podczas pobytu Karimowa w USA można było z oficjalnych wypowiedzi amerykańskich dowiedzieć się, że powstanie tego centrum jest sukcesem polityki Stanów Zjednoczonych wobec Uzbekistanu.

Nic więc dziwnego, że obrońcy praw człowieḱa w Azji Centralnej, z którymi rozmawiałem, czują się zawiedzeni, a niektórzy wręcz oszukani. Każdy, kto wi tym regionie świata decyduje się występować w obronie praw człowieka musi się li- 
czyć $z$ tym, że bedzie w taki czy inny sposób szykanowany przez władze. $W U_{z b e}$
kistanie, ale nie tylko tam, ryzykuje wrecz Centralnej niepodległych państw nadzieje zyyciem. Od czasu powstania w Azji człowieka łączono tam przede wszystkim z poprawe sytuacji w dziedzinie praw jest przypadkiem, że organizacje walczạce polityką Stanów Zjednoczonych. Nic rejonie powstawały przy pomocy pozace o przestrzeganie praw człowieka w tym działalność jest nadal finansowana prządowych organizacji amerykańskich i $i$ czarowanie. Częstokroć jest to uczucie zawodu ponów. Tym większe przeto roz dzie polityki amerykańskiej.

$Z$ tej sytuacji korzystają najwięcej te właśnie reżimy, przeciwko którym skiero-
wana jest działalność obrońców praw człowieka pretowane sąjako prawa grup społecznych, a nie. W Azji prawa człowieka interjako odnoszących się do jednostki powstała nie jednostek. Interpretacja tych praw cje polityki amerykańskiej sq zauważane przez aurze Zachodu. Niekonsekwentyckich. Ich propaganda przedstawia prawa człowiertarnych przywódców azjajako narzucane państwom azjatyckim $w$ celu ustanieka $w$ rozumieniu zachodnim, kontynencie. Podkreślana jest obcość kulturowa żadań ania dominacji USA na tym śnie nadawany rozgłos różnym takim prurowa żądań amerykańskich, a jednoczenów Zjednoczonych wydają się przeczyć dekadkom, w których realia polityki StaReasumując moje wystapienie chce jeslaracjom o celach tej polityki. zacja kwestii praw człowieka w polityce jest raz podkreślić, że instrumentaliważ podważa wiare $w$ uniwersalne obowiazt $w$ moim przekonaniu groźna, poniebezpośredni skutek, że legitymizuje autorytarnanie tych praw. Ma nadto i ten rzystują przykłady instrumentalnego porytarne reżimy polityczne, które wykolityce Zachodu w celu usprawiedliwienia przed kwestii praw człowieka w pokrajach krytykowanych na Zachodzienia przed społeczeństwami we własnych 列

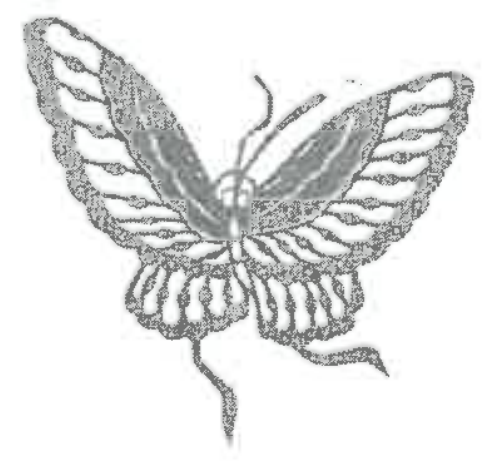

\section{SYLWETKI}

\section{Marceli Burdelski}

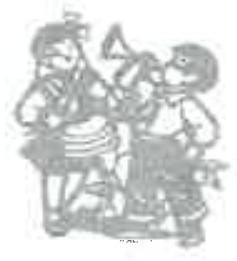

\section{DENG XIAOPING}

Deng Xiaoping (imię nadane przez rodzinę: Xixian), urodził się 22 sierpnia 1904, we wsi Paifang, w powiecie Guan'gan, w prowincji Sichuan. Były to ostatnie lata cesarstwa, a Chiny przeżywały wtedy okres burzliwych reform i rozmaitych ruchów społecznych.

Jego ojciec, Deng Wenmin, był urzędnikiem powiatowym. Miał on sześcioro dzieci, trzech chłopców i trzy dziewczynki, a Xixian był drugim z rodzeństwa. Szkołę podstawową i średnią skończył w swoim rodzinnym powiecie. W $1919 \mathrm{r}$, już po ustanowieniu republiki, został przyjęty do szkoły w Chunqingu, jednym $\mathrm{z}$ dwu centrów kulturalnych tej prowincji. Była to szkoła nowego typu i miała przygotować uczniów do nauki za granica. Reformatorzy inspirowali bowiem wówczas wysyłanie młodzieży do Europy, USA i Japonii dla studiowania dorobku Zachodu i jego nauk, podczas gdy w kraju dominowało jeszcze studiowanie klasyków konfucjańskich. Deng wyjechał wraz z grupą osiemdziesięciu kolegów statkiem do Marsylii. Był najmłodszym $z$ nich, miał zaledwie 16 lat.

Studenci chińscy za granicą wówczas zazwyczaj pracowali, by zdobyć środki na nauke, a organizacje patriotyczne pokrywały im jedynie koszty przejazdu oraz wydatki pierwszych dni. Początkowo Deng pracował w Stalowni Le Cruesset w centralnej części kraju, później w Billancourt na przedmieściach Paryża, w Zakładach Samochodowych Renault jako palacz lokomotywy i pomocnik kuchenny. Krótko uczęszczał do szkół średnich w Bayeth i Chatillon. Na uniwersytet już nie dotarł, gdyż pochłonęła go praca polityczna.

We Francji Deng poznał bowiem działaczy komunistycznych, wśród których wybijał się Zhou Enlai, późniejszy premier ChRL (w latach 1949-1976). W 1922 r wstąpił do Związku Komunistycznej Młodzieży Chińskiej w Europie (później 